\title{
Chapter 2 \\ Diaspora-Centred Development: Current Practice, Critical Commentaries, and Research Priorities
}

\author{
[AU1] Mark Boyle and Rob Kitchin
}

\subsection{Introduction}

It is somewhat counterintuitive to approach migration as an agent of development in sending states. In the past, it was widely believed that emigration was a disadvantage. Emigration signalled that the development trajectory being pursued by a country was failing and that people needed to relocate elsewhere, perhaps against their wishes, to make a living. That emigrants tended to include more able, talented, skilled, and self-starting younger people added to the problem, constituting a 'brain drain'. By starving countries of their best talent, the assumption was that sending states would face even greater difficulties in pursuing growth and development.

This reading of emigration it seems has now been dismissed as dated. The mantra of migration for development has come of age. A seismic shift in thinking and practice within the development sector means that emigrants are now seen as potentially part of the solution to underdevelopment and not part of the problem. Migrants contribute from afar and in a myriad of ways to the betterment of their countries of origin. Diasporic communities themselves have often conceived, financed, and led schemes and programmes targeted at improving their homelands. More recently, sending countries have begun to develop a raft of policies designed to court, lever, harness, and tap their overseas communities. And, these policies have in turn come to be viewed by the international development community as intrinsically virtuous, and international development practitioners have sought

[AU2] to promote, undergird, and pedal the idea of diaspora-centred development

[AU3] (see Yossi and Barth 2003; Lowell and Gerova 2004; Kuznetsov 2006; Saxenian 2006; Vertovec 2007; Solimano 2008; Faist 2008; Dewind and Holdaway 2008; Bakewell 2009; Piper 2009; Leblang 2010).

M. Boyle $(\bowtie) \cdot$ R. Kitchin

Department of Geography/National Institute for Regional and Spatial Analyses,

National University of Ireland Maynooth, Kildare, Ireland 
Countries which actively harness diaspora in the service of development often prepare and are guided by a diaspora strategy. A diaspora strategy is a formal and explicit policy initiative or series of policy initiatives enacted normally by a sending state, or its peoples, aimed at fortifying and developing relationships with expatriate communities, diasporic populations, and foreign constituencies who share a special affinity. Diaspora strategies are most commonly pursued by poor and middle-income countries from the global south. Examples include Armenia, India, Mexico, China, Chile, Argentina, South Africa, Jamaica, El Salvador, Nigeria, South Africa, Tunisia, Ghana, and Morocco. But more affluent countries in the global north with large diaspora populations are also expressing an interest, including Israel, Scotland, Ireland, as well as more developed nations in the south such as Australia, New Zealand, South Africa, and Singapore. Whilst the forms of development being pursued vary in each case, the essential logic underpinning diaspora engagement remains the same: overseas communities have resources and attachments which, if harvested properly, have the potential of accelerating economic growth and development in the home country (Kutzensov 2006; Levitt and Jawroski 2007; Gamlen 2008; Newland 2010; Aikins and White 2011; Boyle and Kitchin 2011).

This chapter provides a review of current practice and reflects upon some emerging areas of critique. Discussion is organized around four principal sections. Sect. 2.2 will chronicle the motives that have led many countries to approach their diaspora as a resource. Sect. 2.3 will then examine the ways in which countries have built new domestic institutions to engage diaspora communities and have sought to intervene in different ways. Attention will then turn in Sect. 2.4 to an exploration of six areas through which diaspora can make a difference: as donors, investors, knowledge networks, markets, brain circulation, and ambassadors. In each case, exemplar diaspora strategy programmes, schemes, and instruments will be identified. Unfortunately, to date diaspora-centred development has tended to be promoted, celebrated, and embraced rather uncritically. In Sect. 2.5 therefore, six areas of emerging critique will be identified and discussed at length. For ease of explication, these six realms of critique will bear the titles: the intellectual deficit, the cottage industry, the chosen few, the citizenship challenge, stakeholder disalignment, and development for whom. The chapter concludes that if the scholarly community is to contribute meaningfully to improvements in the number, scale, equity, inclusivity, sustainability, effectiveness, and quality of diaspora for development projects, a number of new research competencies will be required.

\subsection{The Turn to Diaspora-Centred Development}

Why at this historical moment are a growing number of sending countries seeking to develop explicit and systematic strategies aimed at creating, managing, and energizing relationships with their diasporic populations? It is clear that push factors are coming from three constituencies: diaspora communities themselves, sending state governments, and agencies within destination states. 
Now displaying a heightened awareness of their roles and potential, diasporic populations are self-organizing and creating a range of new institutional structures to deploy their efforts to best effect. The interdisciplinary field of transnational studies has revealed the many ways in which migrant communities can impact upon public, private, and voluntary institutions in their countries of origin (Appadurai 1997; Ong 1999; Pries 1999; Barkan 2003; Vertovec 2003; Tarrow 2005). From hometown associations to agricultural cooperatives, from charities to advocacy groups, from churches and religions to learned medical and scientific academies, from SMEs to pension funds, from political parties to national arts and cultural institutions, from electoral systems to citizenship laws, from terrorist organizations to peace-keeping missions, from satellite TV media to social networking sites, and from university alumni projects to technology transfer, it is clear that diasporic communities have moulded and are moulding their homelands in ways which we are only now understanding. And arguably, they are doing so more reflexively, purposefully, and creatively than hitherto.

For sending states, interest in engaging diasporic populations normally originates in trigger events which arise in one of four policy fields, of which economic development is but one. In addition to development imperatives, sending states are being provoked to action on grounds of nation building, citizenship, and demographic trends. Firstly, whilst historically diasporic groups have played a significant role in nation and state building projects in the homeland and historically nations and states have looked to diasporic groups to promote their interests overseas, the twenty-first century is witnessing a new wave of nation and state building, and as a corollary a fresh and novel impetus for new migrant contributions to and on behalf of political, social, and cultural causes in the homeland. Secondly, growing international migration is challenging the models of citizenship adopted in many sending states, leading to a revisiting and clarification of emigrants' entitlements and obligations and, in some cases, to the introduction of entirely fresh categories of citizenship. Albeit tempered by fears of geopolitical instability and security concerns, yet ever more states are permitting forms of dual and even multiple citizenship. Finally, demographic trends, particularly in low birth rate countries, are leading some countries to engage even more actively in the search for global talent. In the context of tensions over the scale of immigrant inflows, courting the diaspora as a source of brain gain has become something of a preferred policy solution to skills shortages.

For Ireland, diaspora strategy was initially conceived as an opportunity to spend the fiscal surpluses of the Celtic Tiger boom economy (1993-2007) on the protection and welfare of vulnerable and forgotten overseas migrants, but in the wake of the country's economic meltdown (2007-present), diaspora knowledge networks and diaspora tourists are becoming ever more important; for Israel, motivation derives principally from the desire to protect and defend the right of the state of Israel to exist; for Scotland, concern initially was with low fertility levels and the social, economic, political, and cultural consequences of a shrinking population; for New Zealand, the diaspora is seen as a means of countering geographical isolation from the global economy; for Armenia, the diaspora is being seen as a resource in the reassertion and reclamation of a post-Soviet national identity and trajectory; for 
India and China, diasporic groups are being deployed to broker integration into the global economy at a moment when the global distribution of power is being realigned; whilst for Mexico, the efficient harnessing of diasporic remittances is being promoted to counter the effects of population flight from the global south.

It is common for diaspora strategies to broaden out from their point of origin and to populate all three policy fields. Quite how the point of departure (the specific policy field and particular triggers) of any diaspora strategy enables and constrains the subsequent rolling out of this strategy remains to be understood.

Finally, diaspora-centred development is also now being promoted and championed by a whole raft of agencies and institutions in destination states and in particular in the global north. In no particular order, these include:

- The World Bank 'Knowledge for Development Programme', which has supported many collaborative policy workshops and exchanges (recent collaborative events have been held in Buenos Aires, Santiago, Washington, DC, New York, New Delhi, Boston, and Toronto).

- IdEA: In May 2011 in the United States, and at the behest of Hilary Clinton, the Secretary of State's Office of the Global Partnership Initiative (GPI), in collaboration with the Migration Policy Institute (MPI), launched the International diaspora Engagement Alliance (IdEA) at the first ever Secretary's Global Diaspora Forum.

- The MacArthur Foundation, which funded a major research programme titled 'Towards a new generation of diaspora strategies', exploring the role of Diaspora in the Development of Institutions in Sending States (focusing mainly upon India, Mexico, Russia, and Nigeria).

- Diaspora Matters, a not-for-profit company based in Dublin, Ireland, has produced a global diaspora strategies toolkit (2011), a new physical and virtual for a designed to share best practice in the design and implementation of diaspora strategies (live from May 2011).

- The M4D (Migrant for Development) portal is a new joint EU and UNDP website designed to share best practice in diaspora engagement.

- The IOM and MPI Roadmap for Engaging Diasporas in Development published in 2012 represents a summation of those organizations' thinking on the topic and stands as the definitive guide to all stakeholders preparing diaspora-engaging programmes.

- The Economist's special edition in 2012 titled the 'Magic of Diasporas' has proven a well-cited and quoted document and would appear to be influential within policy circles.

\subsection{Designing Diaspora Strategies}

Whilst it is relatively easy to identify branches of state which deal with immigration, it is more difficult to establish who governs over matters of emigration. Cognate state departments and administrative units, such as prime minister's 
offices, departments of foreign affairs, home affairs, heritage and culture, education, trade, and enterprise and development agencies, devise and implement solutions to emigration problems normally in an ad hoc and isolated way. Gamlen (2008) develops the useful notion of the 'emigration state' to capture the totality of the work these range of state actors perform.

A key challenge facing states interested in pursuing diaspora engagement policies is how best to use, augment, and develop their existing emigrant state apparatus. According to Agunias and Newland (2012), among the options adopted to date include the creation of brand new ministry level diaspora institutions, the establishment of hybrid ministries where diaspora engagement is a core brief, the introduction of subministry level institutions, the buttressing of consular and embassy networks, the erection of new regional or local diaspora engagement agencies, and the mobilization of foundations and advisory councils. In turn these institutions have sought to scale up the diaspora-homeland relationship, at one end of the spectrum by manufacturing fresh new connections and at the other by invigorating existing transnational relations.

Within Ireland, the Irish Abroad Unit, a division within the Department of Foreign Affairs, seeks to promote joined-up thinking and coordination across branches of the state, for instance, with respect to the diasporic relevant work of Enterprise Ireland, the Industrial Development Agency, the President's Office, the Department of Education, the Irish tourist authority, and other departments within the state. With respect to the policies of these agencies, the motif of the Irish state is 'let a thousand flowers bloom', with the state at best 'lightly incubating' existing initiatives or seeding new initiatives. The Irish schemes are slowly transferring to more managerialist interventions, especially with regard to accountability and transparency of spending, but there remains an underlying inclination to leave diaspora organizations and networks to run themselves, providing only minimal resources (basic funding, advice, speakers, etc.) and only when an organization or network needs to be re-energized and requires the short-term backing of the Irish state.

A key weakness of the Armenian state in the years immediately following independence from the Soviet Union was the lack of capacity within the state apparatus. Accordingly, across the early 2000s, there has emerged a concerted effort to build the Armenian state and undoubtedly the institutional capacity of the current state represents a momentous improvement on what the country inherited from the Soviet period. The limit of Armenia's prior weak institutional capacity is especially evident when one considers the capacity of the Armenian state to engage, lever, and harness diasporic resources and expertise. Part of the challenge of developing a diaspora strategy then has been the creation of institutional capacity and structures within Armenia capable of extending existing ties and establishing new relationships with the diaspora. Initially, this engagement was largely the preserve of the Ministry of Foreign Affairs and to an extent, the Ministry for Economy. More recently in 2008, a new Ministry of Diaspora was established. This ministry represents a dramatic development in state building in the sphere of diaspora engagement, a significant ramping up of what Armenia is capable of doing with its diaspora. 
India has a well-developed diaspora strategy, which is produced and managed by a dedicated Ministry of Overseas Indian Affairs (MOIA), which came into existence in May 2004 as the Ministry of Non-Resident Indians' Affairs. Within the terminology of the Indian state, this ministry has the status of a 'services' ministry. It is primarily responsible for all issues relevant to overseas Indians-comprising persons of Indian origin (PIOs) and non-resident Indians (NRIs) — which are not specifically allocated to other ministries/departments of the Government of India. Like Armenia, India has found it useful to erect a powerful and central state organ to oversee its ties with its diaspora and more specifically has adopted a highly interventionist posture, setting up schemes and managing programmes directly from New Delhi.

The Scottish government's International Projects Division-instituted by and guided by its International Framework, published in 2008-seeks to promote joined-up thinking and coordination across branches of the state, for instance, with respect to the diasporic relevant work of Scottish Enterprise, Scottish Development International, and VisitScotland. Whilst the International Projects Division performs more as nimble and flexible coordinator than as a key actor itself, and seeks to bring a range of agencies behind the plan, the specific Scottish schemes tend to be highly managerialist in nature. Whilst important exceptions exist, in the Scottish case, the state functions largely as the lead player in proposing, managing, and reviewing schemes. Indeed, Scotland identifies itself as Europe's leading pioneer in the development of formal and systematic state-led diaspora strategies.

New Zealand's diaspora strategy is coordinated and managed by Kea New Zealand, a not-for-profit organization which works in close relation with, but which exists independently from, government. As such, the New Zealand state operates with a light touch and has externalized diaspora strategizing. Kea was conceived and launched at the Knowledge Wave Conference in Auckland in August 2001. Initially funded through private philanthropy, it is now funded in descending order by the government (Ministry of Economic Development and New Zealand Trade and Enterprise), the private sector, sponsorship, service fees, and membership fees (both corporate and individual). It has four full-time regional managers in the UK (London), Australia (Sydney), North America (New York), and China (Shanghai) and 14 international chapters: Los Angeles, San Francisco, New York, Boston, London, Manchester, Paris, Amsterdam, Dubai, Shanghai, Sydney, Melbourne, Brisbane, and Vancouver.

China's approach to its diaspora is being championed by the State Council's General Office of Overseas Chinese Affairs, the Standing Committee of the National People's Congress, and the Political Consultation Conference. Within the Communist Party, the Department of the Unification Front assumes primary responsibility. Whilst these various institutions promote dialogue with respect to how best to engage and cater for the overseas Chinese community, there exists no formal overarching diaspora strategy. Undoubtedly the objective of the Chinese authorities is to secure the loyalty of the overseas Chinese and to engender a sympathetic proBeijing, pro-socialist, but still modern and technologically aware diaspora. In spite of its centralist reputation, much of what the Chinese state does is mainly designed to support initiatives led by diasporic communities and to provide a macro-economic 
regulatory framework which incentivizes diasporic engagement. And more regional diaspora strategies have emerged, nested inside this national framework.

What these administrative arrangements (whom within states are charged with responsibility and how they exercise this responsibility) reveal is that there is no one-size-fits-all approach to formulating and implementing a diaspora strategy, nor should there be. There are very good reasons as to why countries have adopted different approaches, related to the nature and history of their state institutions; the scale, nature, timing, and geography of their diaspora; prior and actually existing relationships with their diaspora; the capacity of domestic private, public, and community organizations; and their geopolitical strengths, weaknesses, and challenges. Indeed, it is unlikely that any government would succeed in building relationships with its diaspora by copying a model pursued by another, though that is not to say

[AU5] that they cannot and should not learn from others. The important point is that a diaspora strategy need not take the form of, or be best served by, neither (a) a highly centralized or highly dispersed set of responsibilities and actors nor (b) a formalized, top-down, bureaucratically regulated, and managerialist blueprint or, on the contrary, a bottom-up, grass roots, diaspora-initiated, and anarchic strategy. Rather a strategy should be developed in a manner that is sensitive to the context in which it will operate and that is most likely to succeed in its aims.

\subsection{Diaspora and Development: Impacts and Projects}

How do diasporas impact upon the development of sending states from afar? It is possible to propose an analytical framework through which the effects of migration on development might be apprehended. A total of six categories of impact are identified. Diaspora can serve as donors, investors, knowledge networks, brain gain, markets, and ambassadors. Recognizing these spheres of influence, governments are beginning to build diaspora strategies, policies, schemes, and programmes to capture, enhance, and ramp up positive contributions in each case.

\subsubsection{Diaspora as Donors}

Migrants can contribute to the welfare of their countries of origin as donors. There are at least two dimensions to this phenomenon: remittances and philanthropy.

Remittances can be defined as private or person-to-person transfers from migrant workers to recipients in the worker's country of origin. In 2010, worldwide remittance flows were estimated at $\$ 440$ billion, $\$ 325$ billion of which were transfers to developing countries (World Bank 2011). To compare, recorded remittances to developing countries were nearly three times the volume of official development assistance (aid), almost equivalent to flows of foreign direct investment (FDI), and almost four times the amount of private loans and portfolio equity (World Bank 2011). 
The United States remains by far the largest source of outward flows, followed by Saudi Arabia, Switzerland, the Russian Federation, Germany, and Italy. In 2010, India, China, Mexico, the Philippines, and France were the top recipient countries (World Bank 2011).

Currently, sending countries (iconic examples being Mexico and El Salvador) are attempting to increase gains from remittances through (a) lowering the cost of transfers and increasing their security; (b) extending transfer services to communities which are 'unbanked'; (c) encouraging collective remittances by providing migrant organizations with technical and organizational support, matching funds, marketing skills, and other business services; (d) stabilizing exchange rates; (e) encouraging more productive uses of remittances; and (f) improving the functioning of the market for remittance services.

Philanthropy can be defined as the private and voluntary donation of resources for charitable and public good. In order of numerical importance, philanthropic giving is coordinated and promoted by private and voluntary organizations (PVOs), religious organizations, corporations, foundations, volunteer citizens, and university and college alumni associations (Hudson Institute 2010).

Johnson (2007) has drawn attention to diaspora philanthropy as an important subset of all philanthropic giving (see also Newland 2010). She identifies two types of diaspora philanthropy, which she terms diaspora associations and diaspora foundations. Diaspora associations are organizations run by and for diaspora groupings who provide philanthropic support directly and indirectly to their members; the most famous example would be the hometown association (HTA) model, especially as managed in Mexico. Diaspora foundations are generally established to facilitate charitable giving to a specific country/region of the world (normally the homeland) and include such foundations as the American India Foundation, the Ireland Funds, the Atlantic Philanthropy, the Ayala Foundation, the Brazil Foundation, Give to Colombia, and Give2Asia.

Aikins, Sands, and White (2011) claim that the diaspora contribute to philanthropy, especially by providing direct gifts of cash, stock, or property; by making wills and bequests; by promoting specific projects and acting as mentors to them; by encouraging governments to create more conducive conditions for giving, particularly in relation to the taxation environment; and by investing in capacity building in non-profit organizations, thereby assisting the non-profit sector to adopt best practice in novel and increasingly important practices such as venture philanthropy, social entrepreneurship, and philanthrocapitalism.

\subsubsection{Diaspora as Investors}

Diasporas can invest in capital markets in countries of origin and can route foreign direct investment to their homelands. Diasporic members can fuel capital markets (portfolio investment) through holding deposit accounts, securitizing remittance flows, providing transnational loans, buying diaspora bonds, and supporting diaspora 
mutual funds (Terrazas 2010a). Institutions most affected are banking institutions, pension funds, insurance companies, and government treasuries. Diasporic members can invest in homelands as senior executives in TNCs, venture capitalists, investors, and outsourcing contracts to SMEs in countries of origin.

China and India are examples of countries which have benefited enormously from diaspora investment. In China's case the so-called bamboo networks have been of particular importance, investing into the Pearl Delta and other parts of mainland China from Hong Kong, Singapore, Australia, Canada, and the United States in particular. The role of Indian entrepreneurs in Silicon Valley in the transferring of technology and the subcontracting of work to Indian companies is also of note. In addition, since 1951 Israel has issued bonds specifically targeted at, but not restricted to, diaspora groupings. Over US\$ 1 billion in bonds is issued each year. Moreover, established in 1993, Yozma is a scheme designed to create joint venture capital funds between the state of Israel and foreign investors, in particular Israeli diaspora members. Meanwhile, the Ameria Group, led by Russia-based Armenian billionaire Ruben Vardanyan, has invested in Armenia companies and now has assets of over US\$500million in Armenia.

\subsubsection{Diaspora as Knowledge Networks}

Diaspora communities can provide soft support to public, private, and community organizations in sending states, by enhancing the knowledge base of indigenous actors and assisting those actors to procure accelerated global command and control capabilities.

Much of the recent excitement over the power of diaspora knowledge networks has stemmed from Saxenian's (2006) pioneering work on ethnic communities in Silicon Valley-Chinese, Indian, Taiwanese, Israeli, and more recently Armenianwho are exploiting their localized social and business webs and tying them into homeland public and private initiatives. Serving as brokers or mentors or gatekeepers, diasporic communities can provide information and guidance on topics as varied as market opportunities, intellectual property rights, upskilling, tax and accountancy regimes, labour law, company law, language needs, ICT, and marketing. They can also serve as a conduit of technological know-how and a channel of technological knowledge transfer.

Most diaspora knowledge networks are relatively new, perhaps less than a decade old, and rely heavily on internet technologies, especially social networking media. Networks vary in their institutional origins (some have grown organically whilst others have been manufactured by homeland states), governance and source of funding (one or other or all of state, NGO, and privately run and financed), sector (some are professional networks which are not sector specific; others are targeted towards specific sectors), and geographical extent (some have regional headquarters and chapters in many countries of the world; others are based only in a single country). Some countries privilege a single network; others benefit from the presence of a 
range of different networks. Examples of the various types and functions of networks can be witnessed in GlobalScot (Scotland), ChileGlobal (Chile), Kea New Zealand (New Zealand), Advance (Australia), Asia Pacific Irish Business Forum (Ireland), The Indus Entrepreneurs (India), and ArmenTech (Armenia).

\subsubsection{Diasporas as Markets}

Diaspora populations can also serve as markets for sending countries, as consumers of domestic goods and nostalgia products, and in particular as tourists.

Tourism is now the world's fourth largest industry. Return visits by diasporic populations to homelands constitute an unquantified but significant section of this lucrative market. According to Agunias and Newland (2012), diaspora tourism includes a broad spectrum of return visits incorporating medical tourism, businessrelated tourism, heritage (or 'roots') tourism, exposure or 'birthright' tours, education tourism, VIP tours, and peak experience tours. The consumption practices of diaspora tourists differ from that of all tourists and tend to generate especially high levels of demand for often labour-intensive or artisanal products. As a consequence, diaspora tourism has the potential to impact particularly favourably on local businesses and local communities. The tourist sector also provides opportunities for diasporic populations to invest in tourism facilities and to open new and perhaps less well-known tourist destinations to wider audiences.

For Agunias and Newland (2010), the central policy challenges presented by diaspora tourism include providing technical support throughout the value chain; easing the flow of people and goods across borders (in particular through user-friendly visa schemes); supporting research, training, and policy development for diaspora tourism, trade, and heritage sites; supporting diaspora-specific marketing and branding efforts; and identifying opportunities for high value-added trade and tourism investments. Examples of recent high-profile diaspora tourism initiatives include Scotland's 'Homecoming Scotland 2009' event and Ireland's 'The Gathering 2013'.

\subsubsection{Diaspora as Brain Gain}

Diasporic populations can promote brain gain through permanent and less permanent forms of return movements.

Programmes designed to encourage brain incubation or circulation remain an important part of some countries' engagement with their diaspora. There exist numerous schemes in such countries as Scotland, Ireland, China, Croatia, Thailand, Canada, Germany, and the Netherlands to reconnect overseas scientists with home, either through return migration or through visiting fellowships. Wang, Zweig, and Lin (2011) provide a profile of the case of China in particular, a country with an 
established reverse brain drain strategy. Terrazas (2010b) also provides a useful overview of programmes which seek to harness the energy of diasporic volunteers even if only for a brief duration. At the supranational scale, the United Nations' Volunteer Programme (UNVP), the International Labour Office' TOKTEN (Transfer of Knowledge Through Expatriate Nationals) initiative, and the International Organization for Migration's (IOM) Migration for Development in Africa (MIDA) scheme attempt likewise to fuse the diasporic appetite to volunteer with schemes designed to lubricate temporary return. Governments can promote volunteering schemes to promote short-term assistance in countries of origin by skilled diaspora volunteers and youth diaspora volunteers, especially in relation to the support of vulnerable populations, the provision of skills that are in short supply, and to assist in the administration of aid, not least following a natural or a human-induced disaster.

\subsubsection{Diaspora as Ambassadors}

Advocates, activists, agitators, and ambassadors within diasporic communities can exploit their knowledge, contacts, linguistic skills, and cultural insights to promote peace and security in their homelands and to enhance the strategic, diplomatic, and foreign policy objectives of their countries of origin.

Of course there exists much debate over the extent to which diasporas contribute more to conflict and political anarchy in homelands than to conflict resolution and progressive statecraft (Shain and Barth 2003). But Brinkerhoff (2009) argues that it is no longer possible to view diasporas as mere adjuncts to homeland conflicts and provides a valuable summary of the conditions in which diaspora might serve as 'conflict entrepreneurs', 'competing interests', or 'contributors to stability and development'.

Ireland, for instance, has benefited from advocacy work conducted by its diaspora. Once a contributor to conflict and an impediment to peaceable relations between Britain and Ireland, the Irish diaspora has emerged as a powerful partner for peace. In the 1990s, for instance, Irish America worked closely with the Clinton administration in the United States and political parties in Northern Ireland to make important contributions to the Northern Ireland peace process. Subsequently, it has played a role in channelling investment into Belfast, Derry, and border regions to buttress peace building.

Canada's role as a global immigrant magnet and leading proponent of multiculturalism, and the important subset of Canadians abroad who are naturalized Canadians, has provided that country with a fundamentally unique resource. In the Canadian Department of Foreign Affairs and International Trade (DFAIT) concept of the 'global citizen', Canada has an opportunity to harness its diaspora for geopolitical ends (The Mosaic Institute and Walter and Duncan Gordon Foundation 2011). The concept of the 'global citizen'-incorporating as it does all constituencies in Canada with resources which might help the country enhance its global activities 
and relations (including other countries' diaspora in Canada, whether naturalized or not, and Canadian-minded populations overseas, whether Canadian citizens or not and whether naturalized or Canadian born)—significantly broadens the populations with which diaspora strategies might conceivably engage.

\subsection{Emerging Strands of Critique}

Undoubtedly, the diaspora for development agenda has proliferated without significant critical introspection and commentary. This is not altogether surprising; this agenda has enjoyed a certain celebrity status of late and as with many zeitgeist concepts, advocates and proponents have displayed certain kind of blind loyalty. But sufficient time has now elapsed and experience garnered to be able to raise a number of critical questions that merit further rumination and scrutiny. Here we point to six lines of critique which would appear to be emerging as of particular concern: the neglected intellectual bases of the agenda, the degree to which an unhelpful cottage industry has surfaced around it, the extent to which the concept of the diaspora is being mobilized wittingly or unwittingly to include and exclude certain communities, the failure to think through how citizenship rules might affect and be affected by diaspora-centred development, the extent to which the multiple stakeholders involved in diaspora strategies are being aligned, and, finally, the question of who development benefits, where, how, and why.

\subsubsection{The Intellectual Deficit}

The diaspora for development agenda would appear to lack firm intellectual foundations and roots within both the migration and the development studies literatures. This intellectual deficit in part derives from the fact that there exists no consensus within either the migration or the development studies literature as to how contemporary 'diaspora' and 'development' might best be theorized as separate entities let alone together. It also has its origins in the fact that the agenda has demanded a conversation between migration experts and scholars of development and each constituency has been forced to learn anew an entirely new intellectual tradition. This conversation has proven painful and is only in its infancy. The consequence has been the overwhelming tendency to date for research to be policy and consultancy oriented.

Perhaps, Larner (2007) and Gamlen (2012) have made the greatest progress by attempting to study diaspora strategies as instruments of neoliberal economic development strategies. To the extent that there is merit in this argument, a political discussion then follows. Liberals and neoliberals who view development in terms of competition within the global capitalist economy might celebrate diaspora strategies as a new source of global competitive advantage. Given that diaspora networks have 
the potential to broker weaker nations into the global economy, these networks might even be said to be contributing to a more equitable and flatter world. More critical accounts, including variants of world systems analyses and dependency theory, in contrast might point to the importance of histories of world capitalist expansion, colonialism, post-colonialism, and neocolonialism. Diaspora strategies might be said to be a distraction, yet another western-centric concept of development which is failing to address the root causes of underdevelopment and poverty. Indeed, diaspora strategies might be approached as promoting forms of governmentality in both the diaspora and the homeland which are designed to discipline and cultivate neoliberal subjects. Diaspora strategies inculcate cultural values which are designed to support the hegemony of the contemporary global capitalist economy.

Others again point to the recent development of third way philosophies of development, paying attention to the need to build community capacity and social capital in developing nations as an alternative to both free market capitalism and overly muscular 'nanny states' (Faist 2008). Here, the role of diaspora organizations and networks might be approached in terms of their capacity to furnish communities with forms of cultural, social, economic, and political capital which help them to help themselves. Neither the market nor the state can develop societies; only active citizens and fortified community capacity can create sustainable development. The role of the state is to create conditions in which social capital might prosper and diaspora strategizing represents one domain in which the incubation of effective social capital is possible.

Some suggestive theoretical strands exist therefore. But to what extent can the diaspora for development agenda simply be appropriated and rendered intelligible within the terms of say existing approaches and their mutants? Alternatively, would reading this agenda through the lens of existing theoretical and conceptual traditions not obfuscate the novelty and originality of the forms of development the agenda is promoting? If so, what kinds of new theoretical and conceptual schema might be appropriate, and how might these schema contribute to and enrich thinking within the fields of migration and development studies and practice?

\subsubsection{The Cottage Industry}

The diaspora for development agenda is an agenda on the rise. Like any idea whose time has come, however, it has opened up a 'career space' which a number of commentators, politicians, business leaders, civil servants, conference organizers, consultancy firms, and academics have been only too glad to fill. The consequence is that many constituencies now have a personal stake in the agenda and are building biographies which are dependent upon its proliferation. A political economy of the very idea of diaspora for development has emerged. A circuit of people and ideas has surfaced that has steadily developed into a trade of sorts. In such circumstances, there is a danger that hype may triumph over reality and disproportionate claims may be pedalled. 
Kuznetsov (2011) builds a case in support of a 'new generation of diaspora initiatives' which are better equipped to harness diasporic groupings in the building of institutions in sending states. Kuznetsov's desire to rethink and refocus practice is rooted in reservations he has concerning the unwarranted pomp, fanfare, and associated coterie that appears to be clustering around diaspora strategies. In too many cases, ill-defined and overly broad diaspora constituencies are being engaged; wasteful, unnecessary, and ineffective centralized blueprints and bureaucracies are being imposed on an already crowded landscape of purposeful and effectual organic transnational relations; and diaspora strategies are becoming all-consuming ends in themselves. For Kuznetsov, there is a pressing need to adopt a new, pragmatic approach. Kuznetsov calls for a purposeful reorientation of effort, in which diasporic elites are engaged only in so far as these movers and shakers can contribute meaningfully to the achievement of specific, finite, concrete, and strategic national objectives.

To what extent and in what ways is a political economy of the very idea of diaspora for development emerging? Who is pedalling this idea, through what means, and towards what ends? Who is benefiting from the rise of this agenda? How are proponents advocating and policing the agenda? Is the current shift of people, resources, effort, ideas, and institutions necessary and proportionate given the scale of development added endeavour might bring?

\subsubsection{The Chosen Few}

The concept of diaspora has a long and complex genealogy. Of course for some, the idea refers exclusively to the forced migration of those rendered vulnerable or victims as a consequence of a natural or human disaster. Much of this historical resonance has dissipated. Many diaspora strategies now identify their target audience to include all expatriates who have scattered from the home state for a range of reasons and/or who feel emotionally connected to their place of origin. But by widening the definition arguably diaspora strategies have fashioned a concept which is flexible enough to be capable of excluding as well as including certain communities.

An asset for a successful diaspora strategy is a loyal and motivated diaspora, willing and minded to contribute to national development. To this end, some countries promote short-term visits designed to energize future diasporic leaders and which will sow the seeds for a lifelong commitment and loyalty. Examples are the Taglit-Birthright Israel and MASA programmes, which repatriate Jewish youth to Israel, and the Know India Programme. Countries may also provide specific services relating to cultural identity. For example, India has set up a statesponsored genealogy service, 'Tracing Roots', which engages a private company (Indiroots) to construct a family tree for a small fee. Similarly, the Lithuanian government funds Lithuanian schools to teach the Lithuanian language and cultural heritage to the descendants of Lithuanian emigrants. Some nations also make use of national honours and awards systems to build diasporic loyalty by recognizing 
the contribution of individual diaspora members to the homeland and to society in general. For example, since 2003, the President of India has presented the Pravasi

[AU9] Bharatiya Samman (recognition of non-resident Indians) awards to up to 20 members of the Indian diaspora, the highest civilian honour which can be bestowed

[AU10] on overseas citizens. In 2006, KEA New Zealand started the World Class New Zealand Awards to honour New Zealanders who had made significant international contribution in different spheres. Some countries have also set up formal arrangements of consultation with their diasporas. For example, Jamaica has established the Jamaican Diaspora Advisory Board. Its members are elected and it meets twice a year to discuss diaspora matters.

There is great virtue in schemes such as these. But it could be argued that projects designed to build the diaspora are calling to the fore only a narrow group of invented or imagined communities. And like all imagined communities of the nation, some people may get to be more included than others. Certainly Ho (2011) is of the view that diaspora strategies invent ideas of diaspora and in so doing approach, valorize, and incorporate only a subset of overseas migrant communities. The risk is that only diaspora elites capable of delivering development for sending states will be prioritized. Moreover perhaps only communities who sign up to particular narratives of the nation will be appealed to; minority communities, even if citizens of a nation, may be overlooked.

Might diaspora strategies be said to be creating diaspora communities as much as engaging them? Which kinds of communities are diaspora strategies conjuring

[AU11] up? Who is included and who is excluded? What are the social, political, cultural, and economic costs and consequences of the selective concepts and definition to diaspora which diaspora strategies are predicated upon.

\subsubsection{The Citizenship Challenge}

To date, it might be argued that diaspora strategies have paid insufficient attention to citizenship rules. And yet citizenship rules clearly mediate the extent to which diasporic communities are able to contribute to their homelands and in turn are shaped by ongoing debates as to the extent to which diasporas can be approached both as a resource and as an obligation.

The concept of citizenship has a long and fraught history, further complicated now by debate as to the legal status and associated rights and obligations sending governments might bestow on migrant populations. These rights and obligations incorporate civil (legal protection, guarantee of freedoms, security), political (voting and political participation), social (social security, education, housing, and health services), and economic (work and taxation) spheres. Fox (2005) and Bloemraad, Korteweg, and Yurdakul (2008) provide useful overviews of the implications of large-scale migration for traditional models of citizenship. The concept of dual citizenship would seem particularly important today: Dual or multi-citizenship refers to the ascription of various kinds of citizenship to migrants in both the 
sending country and one or more destination country. In the past decade, there has been a proliferation of countries who are now prepared to offer citizenship to migrants without requiring them to renounce or annul their citizenship status in their countries of origin (see Macklin and Crépeau 2010).

For sending states, the question of extending citizenship rights to overseas groups risks exposing them to unmanageable fiscal pressures (commitments which are difficult to service), domestic political risks (allowing diasporic groups to shape election outcomes or gain access to services without taxation), and diplomatic and geopolitical strains (more porous borders, being seen to intervene on behalf of citizens in countries where that intervention is not welcome and is likely to breach important relations). But it is obvious that any project which seeks to build new relationships between sending states and diasporic populations will only be sustainable if both groups feel they have a meaningful stake in the project and will enjoy mutual benefits from ensuring its success. Countries around the world are wrestling with the problem of formulating progressive and yet secure, operational, and defensible dual citizenship policies, and few seem to have found a formula that might attract the accolade of best practice.

How far do diaspora strategies create a new context for the writing and revision of citizenship rules? How are diaspora strategies enabled and constrained by existing citizenship arrangements? How might existing arrangements be modified so as to lubricate the contributions which the diaspora might make without losing sovereign control over national borders and exposing countries to undesirable risks?

\subsubsection{Stakeholder Disalignment}

All too often it is assumed that diaspora strategies need to focus only in building relationships between sending states and diaspora populations. This focus is however too narrow. Diaspora strategies will fail if no effort is made to interact with and to engage key stakeholders both within sending states and within destination states.

In fact, the role of global diasporas in the development of countries of origin is conditioned by (a) the development of an effective diaspora strategy in sending states; (b) the scale, history, geography, and dynamics of particular diaspora; (c) a range of public, private, and community stakeholders in sending countries; and (d) the external aid, trade, diplomatic, security, and immigration priorities of destination countries. There exists a unique nexus in each case and it is this unique nexus which mediates, energizes, brokers, and frustrates the contributions of diasporic groupings to homeland development differently in each case. Diaspora schemes which are successful and which are presented as exemplars of best practice are often predicated upon a strong collaborative alignment between sending state strategies, diaspora aspirations and agendas, and the priorities of destination countries. Diaspora schemes which are transferred from pioneers to adopters often enjoy more limited success because these adopters display lesser degrees of collaborative alignment. Novel diaspora schemes which are piloted in pioneering 
countries often enjoy limited success because these pioneers display insufficient prior collaborative alignment to underpin successful implementation. Of course degrees of collaborative alignment and disalignment will vary not only between diaspora but through time.

How far are diaspora strategies paying attention to the wider group of stakeholders they need to engage with? Are strategies failing not because they lack merit in their own design and resourcing but because they are failing to mobilize the range of stakeholders needed to bring success? How might diaspora strategies be made to align themselves more clearly with stakeholder groups?

\subsubsection{Development, But for Whom?}

In part because of the novelty of the diaspora for development agenda, insufficient attention has been paid thus far to the forms of development which diaspora strategies promote. Development is always socially and spatially variable in its impacts and there is a need to better understand who benefits most, where, why, and how?

Notwithstanding aspirational claims and lofty ambitions, it has to be remembered that research into the economic resources and opportunities which sending countries might procure from diasporic communities is only in its infancy. In the absence of research findings, reliance is often placed upon paradigmatic case studies, more often than not selected to promote the virtuosity of flagship initiatives. Early findings, however, point to mixed results.

Nielsen and Riddle (2007) examined why members of diaspora populations invest in their homelands. They observed that intra-diaspora cultural differences, support for diaspora organizations, and three types of investment expectationsfinancial, social, and emotional-were key to understanding migrant motivations. Meanwhile Agrawal et al.'s (2010) study of the impact of emigration from India on domestic innovation within Indian companies concludes that innovation rates among returning Indian émigrés are no greater than among those who stayed put, that knowledge transfer from the Indian diaspora is not sufficient to offset the losses incurred by emigration, that diasporic knowledge transfer has greater benefits only for high value-added innovations, and therefore that skilled emigration has a generally harmful effect on the Indian economy. Leblang (2010) meanwhile provides evidence that even after controlling for intervening variables, connections between migrants residing in investing countries and their home country do influence patterns of global investment by reducing both transactional and information costs.

There is a certain sense that diaspora strategies work most effectively for the existing elites in sending states and may as a consequence simply reproduce and intensify existing social and spatial inequalities. The haves most able to engage diasporic communities benefit most whilst the impoverished benefit least. Those communities based in regions with greater levels of development benefit whilst those dwelling in laggard regions fall further behind. Regional polarization widens. But this interpretation of the socio-economic footprint of diaspora strategies is at 
best premature and may in fact be unnecessarily pessimistic. In a whole number of ways, and not just with respect to diaspora remittances and philanthropy, the development opportunities which diasporic populations bring percolate further and deeper into regions, cities, and communities than might be anticipated. In part this reach occurs because historically it is the most disadvantaged communities and regions which have witnessed the greatest emigration. When these emigrants engage with home, it is in part to their specific point of origin that they are drawn.

What forms of development do diaspora strategies bring? Do these strategies merely serve to consolidate existing and ingrained social and spatial inequalities? If not why and in what ways might diaspora for development be said to be promoting more socially and spatially inclusive forms of development? Why kinds of interventions might contribute to the fortification of more progressive diaspora for development programmes?

\subsection{Conclusion: Building Research Capacity for a New Generation of Diaspora-Centred Developments}

It is hoped that in so far as it has offered a status report on where the field is at today, and ruminated on important areas of emerging critical commentary, this chapter will serve as an introduction to the more detailed papers on specific schemes, challenges, case studies, countries, and problems which will follow.

The diaspora-centred development agenda is important and has great potential. It is clearly here to stay. It is incumbent therefore upon the scholarly community to conduct research which will assist, develop, improve, and revise the diaspora strategies that are now being designed, implemented, and monitored. The research community has a role to play in the promotion of a new generation of more sustainable, equitable, effective, progressive, and inclusive diaspora for development programmes and initiatives.

To this end, it is perhaps useful to conclude by drawing attention to the key competencies which the research community might need to develop, if it is to play a purposeful role into the future. These include:

- Expanding interdisciplinary literacy: The research community will need to develop a more secure intellectual and scholarly foundation for the claim that diaspora can positively assist in the development of sending states. This claim demands knowledge of a range of disciplinary perspectives. Researchers will need to gain a better interdisciplinary knowledge of the problem specifically with respect to the differing perspectives which exist in the disciplines of development studies, international affairs (not least this discipline's particular expertise in comparative studies), and migration studies.

- Competency in the field of policy transfer: To date, comparisons and policy exchanges have been insufficiently reflexive and ideas have circulated opportunistically and on occasions casually, carelessly, and inappropriately. In offering 
policy prescriptions, researchers need to engage more effectively the large public policy literature on policy impact analyses and policy transfer in political science. Such engagement will improve the quality of the advocacy of particular models as best practice.

- Methodological competency in new cultural settings: There is a need to establish a wider set of methodological competencies. It is imperative that comparative research, and in particular field research, is undertaken in a wide range of challenging development and cultural environments, in Europe, in Central and South America, Africa, Asia, the Middle East, and Oceania. For instance, researchers need to upskill in conducting online surveys in cross-cultural contexts.

- Research management skills and consortium building: The scale and breadth of the research programmes that are required surpasses that which are routinely launched between research institutes. Exposure to high-level project manage-

[AU12] ment skills will be required to breed a new generation of PIs for large research programmes. Researchers will need to develop and extend international research networks and will need to establish a deeper presence in globally significant academic and policy networks.

- Developing outreach skills and reach multiple publics: The research community needs to sharpen its skill set regarding creating and disseminating applied and publicly useful knowledge to a wider range of actors beyond the academy. A new generation of public intellectuals with expertise in diaspora and development is needed.

- Capacity to educate both the general student body (as good citizens) and future leaders in the NGO/development sector: Research-led teaching should introduce new graduate-level masters and $\mathrm{PhD}$ students—and, crucially, external partners [AU13] who wish to attend CPD classes - to the fields of migration and development.

\section{[AU14] References}

Agrawal, A., Kapur, D., McHale, J., \& Oettl, A. (2010). Brain drain or brain bank? The impact of skilled emigration on poor-country innovation. Journal of Economics, 21, 172-187.

Agunias, D. R., \& Newland, K. (2012). Developing a road map for engaging diasporas in development: A handbook for policymakers and practitioners in home and host countries. Washington: IOM, MPI.

Aikins, K., \& White, N. (2011). Global diaspora strategies toolkit. Dublin: Ireland Funds.

Appadurai, A. (1997). Modernity at large: Cultural dimensions of globalization. Oxford: Oxford University Press.

Bakewell, O. (2009). Migration, diasporas, and development: Some critical perspectives. Jahrbucherf. Nationalokonomie u Statistik, 229, 787-802.

[AU15] Barkan, E. R. (Ed.). (2003). Immigration, incorporation and transnationalism. New Jersy: Transaction Publishers.

Bloemraad, I., Korteweg, A., \& Yurdakul, G. (2008). Citizenship and immigration: Multiculturalism, assimilation, and challenges to the nation state. Annual Reviews of Sociology, 34, 153-179.

Boyle, M., \& Kitchin, R. (2011). A diaspora strategy for Canada? Enriching debate through Heightening awareness of international practice. Vancouver: Asia Pacific Foundation of Canada. 
Brinkerhoff, J. M. (2009). Diasporas and conflicted societies: conflict entrepreneurs, competing interests, or contributors to stability and development? Global effects and local dynamics of intra state conflicts international workshop, Jerusalem.

Dewind, J., \& Holdaway, J. (Eds.). (2008). Migration and development within and across borders: Research and policy perspectives on internal and international migration. Geneva: IMO.

Faist, T. (2008). Migrants as transnational development agents: an inquiry into the newest round of the migration-development nexus. Population Space and Place, 14, $21-42$.

Fox, J. (2005). Unpacking 'transnational citizenship. Annual Reviews of Political Science, 8, 171-201.

Gamlen, A. (2008). The emigration state and the modern geographical imagination. Political Geography, 27, 840-856.

Gamlen, A. (2012). Creating and destroying diaspora strategies: New Zealand's emigration policies re-examined. Transactions of the Institute of British Geographers (Published Online April 2012).

Ho, E. (2011). 'Claiming' the diaspora: Elite mobility, sending state strategies, and the spatialities of citizenship. Progress in Human Geography, 40, 1-16.

Hudson Institute. (2010). The index of global philanthropy and remittances. Washington: Hudson Institute.

Johnson, P. D. (2007). Diaspora philanthropy : Influences, initiatives, and issues. Harvard: The global equity initiative.

Kuznetsov, Y. (Ed.). (2006). Diaspora networks and the international migration of skills - How countries can draw on their talent abroad. Washington, DC: World Bank Institute, WBI Development Studies.

Kuznetsov, Y. (2011). How can countries talent abroad help transform institutions at home (Diaspora strategies toolkit). Dublin.

Lainer-Vos, D. (2010). Diaspora-homeland relations as a framework to examine nation building. Sociology Compass, 4, 894-908.

Larner, W. (2007). Expatriate experts and globalising governmentalities: The New Zealand diaspora strategy. Transaction of the Institute of British Geographers NS, 32, 331-345.

Leblang, D. (2010). Familiarity breeds investment: Diaspora networks and international investment. American Political Science Review, 104, 584-600.

Levitt, P., \& Jawroski, B. N. (2007). Transnational migration studies: Past developments and future trends. Annual Review of Sociology, 33, 129-156.

Lowell, B. L., \& Gerova, S. G. (2004). Diasporas and economic development: State of knowledge. Washington: Institute of the Study of International migration, Georgetown University.

Macklin, A., \& Crépeau, F. (2010). Multiple citizenship, identity and entitlement in Canada (IRPP study no. 6). Montreal: Institute for Research on Public Policy, University of McGill.

Mosaic Institute and Walter \& Duncan Gordon Foundation. (2011). Tapping our potential: Diaspora communities and Canadian foreign policy. Toronto: The Mosaic Institute and Walter \& Duncan Gordon Foundation.

Newland, K. (Ed.). (2010). Diasporas: New partners in global development policy. Washington: Migration Policy Institute.

Nielsen, T. M., \& Riddle, L. (2007). Why diasporas invest in the Homeland: A conceptual model of motivation. Washington: George Washington University.

Ong, A. (1999). Flexible citizenship: The cultural logics of transnationality. Durham: Duke University Press.

Piper, N. (Ed.) (2009). Rethinking the migration-development Nexus bringing marginalized visions and actors to the fore. Population Space and Place Special, 15Pages, 93-203.

Pries, L. (1999). Migration and transnational social spaces. Aldershot: Ashgate.

Saxenian, A. (2006). The new Argonauts: Regional advantage in a global economy. Cambridge, MA: Harvard University Press.

Tarrow, S. (2005). The new transnational activism. Cambridge: Cambridge University Press.

Solimano, A. (Ed.). (2008). The international mobility of talent. Types, causes, and development impact. Oxford: Oxford University Press.

Terrazas, A. (2010a). Diaspora investment in developing and emerging country capital markets: Patterns and prospects. Washington: Migration Policy institute. 
2 Diaspora-Centred Development: Current Practice, Critical Commentaries...

Terrazas, A. (2010b). Connected through service: Diaspora volunteers and global development. Washington: Migration Policy Institute.

Vertovec, S. (2003). ESRC research programme on transnational communities: Programme Directors final report. Swindon: ESRC.

Vertovec, S. (2007). Circular migration: The way forward in global policy. Oxford: International migration Institute.

Wang, H., Zweig, D., \& Lin, X. (2011). Returnee entrepreneurs: Impact on China's globalization process. Journal of Contemporary China, 20(70), 413-431.

World Bank. (2011). Migration and remittances factbook 2011 (2nd ed.). Washington: World Bank.

Yossi, S., \& Barth, A. (2003). Diasporas and international relations theory. International Organization, 57, 449-479.

[AU18] Zweig, D. Returnee Entrepreneurs. 